Eskişehir Osmangazi Üniversitesi Mühendislik ve

Mimarlık Fakültesi Dergisi 27(2), 60-66, 2019
Journal of Engineering and Architecture Faculty of

Eskisehir Osmangazi University 27(2), 60-66, 2019

\title{
BETONARME VE YIĞMA BİNALARDA KENTSEL DÖNÜŞÜM UYGULAMALARI: KÜTAHYA ÖRNEĞi
}

\author{
Ersin GÜLER ${ }^{1}$, Mehmet CANBAZ², H. Selim ŞENGEL ${ }^{3 *}$ \\ ${ }^{1}$ Eskiş̧ehir Osmangazi Üniversitesi, Sivrihisar M.Y.O., İnşaat Teknolojisi Bölümü, Sivrihisar, Eskişehir, ORCID No : \\ http://orcid.org/0000-0002-5679-8838 \\ ${ }^{2}$ Eskişehir Osmangazi Üniversitesi, Mühendislik Mimarlık Fakültesi, Batı Meșelik Yerleșkesi, İnşaat Müh. Böl. 26480 \\ Eskișehir, ORCID No : http://orcid.org/0000-0002-0175-6155 \\ ${ }^{3}$ Eskişehir Osmangazi Üniversitesi, Mühendislik Mimarlık Fakültesi, Batı Meșelik Yerleșkesi, İnşaat Müh.Böl., 26480 \\ Eskişehir, ORCID No : http://orcid.org/0000-0002-9103-8869
}

\begin{tabular}{l}
\hline Anahtar Kelimele \\
\hline Kütahya, \\
Kentsel dönüşüm, \\
Risk, \\
Betonarme, \\
Yığma yapılar
\end{tabular}
Öz

http://dx.doi.org/10.31796/ogummf.543246

Sanayileşmenin artmasından sonra şehirlere olan hızl göç nedeniyle çarpık yapılaşma ve gecekondulaşma artmıștır. Deprem kuşağında yer alan Türkiye'de bu yapıların artması nedeniyle can ve mal kayıpları meydana gelmistitir. Bu yapıların en hızlı ve kolay dönüștürülmesinin yollarından biri kentsel dönüşümdür. Kentsel dönüşüm, şehirlerdeki çarpık yapılașma, altyapı, ulașım vb sorunları, çözüme kavușturmak için bir bölgenin ekonomik, fiziksel, sosyal ve çevresel koşullarına kalıcı bir çözüm üretmek için kapsamlı bir eylem planı olarak ifade edilmektedir. Kentsel dönüşüm Dünya'da olduğu gibi ülkemizde de yayginlaşmaktadır. Kentsel dönüşüm kapsamında gerekli yasalar çıkarılmakta ve insanlar bu konuda bilgilendirilmektedir. Bu çalışmada Kütahya ilinde Afet Riski Altındaki Alanların Dönüştürülmesi Hakkındaki Kanunun yürürlüğe girdiği tarihten 2016 yılına kadar bireysel bașvuru yöntemi ile kentsel dönüșüm kapsamında değerlendirilen 66 betonarme ve 269 ylğma-karma binaya ait riskli bina inceleme formları irdelenmiştir. Elde edilen verilerin değerlendirilmesi ile kent merkezinde bulunan yığma-karma ve betonarme yapıların karakteristik özelikleri belirlenmiștir. Bu kapsamda öneriler sunulmuş ve kentsel dönüşüm uygulamalarında bu çalış̧madan yararlanılması düşünülmüştür.

\section{URBAN TRANSFORMATION APPLICATIONS IN REINFORCED CONCRETE AND MASONRY BUILDINGS: THE CASE OF KÜTAHYA}

\begin{tabular}{l}
\hline Keywords \\
\hline Kütahya, \\
Urban transformation, \\
Risk, \\
Reinforced concrete, \\
Masonry structures
\end{tabular}
Abstract

Rapid migration to cities after the increase of industrialization has resulted in distorted settlement and slums. Located in the earthquake zone of life and property losses due to the increase of these structures occurred in Turkey. One of the fastest and easiest ways of transforming these structures is urban transformation. Urban transformation is expressed as a comprehensive action plan that aims to provide a lasting solution to the economic, physical, social and environmental conditions of a diverting region in order to solve the problems in the cities. Urban transformation is spreading in our country as it is in the world. The necessary laws are being enacted within the context of urban transformation and people are informed about this issue. In this study, risky building examination forms belonging to 66 reinforced concrete and 269 masonry-mixed buildings evaluated under the scope of urban transformation by individual application method were examined from the date when the Law on the Conversion of Areas Under Disaster Relief entered into force in the city of Kütahya until 2016. By evaluating the obtained data, the characteristics of the masonry-mixed and reinforced concrete structures in the city center have been determined. Suggestions are presented in this context and urban transformation applications are considered to be used without this work.

\footnotetext{
*Sorumlu yazar; e-posta : ssengel@ogu.edu.tr
} 
Eskişehir Osmangazi Üniversitesi Mühendislik ve Mimarlık Fakültesi Dergisi 27(2), 60-66, 2019
Journal of Engineering and Architecture Faculty of Eskisehir Osmangazi University 27(2), 60-66, 2019

\begin{tabular}{llll}
\hline Araştırma Makalesi & & Research Article & \\
Başvuru Tarihi & $: 22.03 .2019$ & Submission Date & $: 22.03 .2019$ \\
Kabul Tarihi & $: 06.05 .2019$ & Accepted Date & $: 06.05 .2019$ \\
\hline
\end{tabular}

\section{Giriș}

Kentler, sanayileşmenin artması nedeniyle göç almaya başlamış ve yapılaşma hızlı bir şekilde artmıştır. Yapılaşmanın artması beraberinde kentlerde sorunları beraberinde getirmiștir. Hızlı nüfus artışı, altyapı yetersizliği ve çarpık yapılaşma nedeniyle kentsel gelişim plansız olarak ilerlemiştir. Bu nedenlerden dolayı kentsel dönüşüm günümüzde önemli konulardan biridir.

Ülkemizde kentsel dönüşüm alanında yapılan çalışmalar son yıllarda, özellikle 1999 Marmara ve Düzce Depremlerinde oluşan yıkımlarla daha da konuşulmaya ve tartışılmaya başlamıştır. Afet riski altındaki alanların azaltılması ve gecekondu alanlarının dönüşümü için kentsel dönüşüm projeleri uygulanmaya başlanmıştır (Genç, 2008; Beyaz ve Livaoğlu, 2019). Bu çalışmaların yapılabilmesi için 6306 sayılı "Afet Riski Altındaki Alanların Dönüștürülmesi Hakkında Kanun" çıkarılmıştır. Bu kanunun amacı, afet riski altındaki alanlar ile bu alanlar dışındaki riskli yapıların bulunduğu arsa ve arazilerde, fen ve sanat norm ve standartlarına uygun, sağlıklı ve güvenli yaşama çevrelerini teşkil etmek üzere iyileştirme, tasfiye ve yenilemelere dair usul ve esasları belirlemektir (Afet riski altındaki alanların dönüștürülmesi hakkında kanun, 2012).

$\mathrm{Bu}$ çalışmada Kütahya ilinde Afet Riski Altındaki Alanların Dönüștürülmesi Hakkındaki Kanunun yürürlüğe girdiği tarihten itibaren 2016 yllına kadar yapılan bireysel başvuru yöntemi ile kentsel dönüşüm kapsamında değerlendirilen 66 betonarme ve 269 yığma-karma binaya ait riskli bina inceleme formları irdelenmiștir. Elde edilen verilerin değerlendirilmesi ile kent merkezinde bulunan yı̆̆ma-karma ve betonarme yapıların karakteristik özelikleri belirlenmiştir.

\section{Yöntem}

Kütahya'da 6306 Sayılı Afet Riski Altındaki Alanların Dönüștürülmesi Hakkındaki Kanunun yürürlüğe girdiği tarihten itibaren 2016 yılına kadar yapılan bireysel bașvuru yöntemi ile kentsel dönüșüm kapsamında dönüştürülen 66 betonarme yapı ve 269 yığma-karma yapıya ait riskli bina tespit inceleme formları irdelenmiştir. Öncelikle yapılara ait bilgiler verilmiş ve taşıyıcı sistemleri incelenmiştir. Yapıların mevcut durumları ile yapılan performans analizleri grafikler üzerinde karşılaştırılmış ve değerlendirilmiştir.

\section{Değerlendirme}

Kentsel dönüşüm kapsamında incelenen yapılar için önce genel bir değerlendirilme yapılmış sonra yı̆̆ma, karma ve betonarme yapılar olarak ayrı ayrı ele alınmıştır.

\subsection{Yapıların Genel Değerlendirilmesi}

$\mathrm{Bu}$ kısımda incelenen yapıların yapım yıl, kat adedi, bina yüksekliği, toplam inşaat alanı gibi genel bilgiler dikkate alınarak elde edilen grafiklerle değerlendirildi. Şekil 1'de kentsel dönüşüm kapsamında incelenen yapıların inşa edildiği yıla göre dağılımı gösterilmiştir. Şekil 1 incelendiğinde yığma ve karma yapıların \% 11'i 1960 yılı öncesinde, \%1 gibi çok küçük bir bölümü ise 2000 yılı sonrasında, \% 88 gibi önemli bir kısımda 19602000 yılları arasında yapılmıștır. Kentsel dönüşüme giren betonarme binaların \% 95'i 1970-2000 yılları arasında inșa edildiği görülmüștür. Yapılan incelemede 1975 yılı Deprem Yönetmeliği'nden sonra inşa edilen betonarme yapıların sayılarının arttığı, buna bağlı olarak kentsel dönüşüm için başvurulan betonarme bina sayısı arttı̆̆l, ancak 1998 Deprem Yönetmeliği sonrasında yapılan yapıların sahiplerinin kentsel dönüşüm için oldukça az başvuruda bulunduğu dolayısı ile bu yapıların kentsel dönüşümü için yeterli risk oluşturmadığı düşünülebilir.

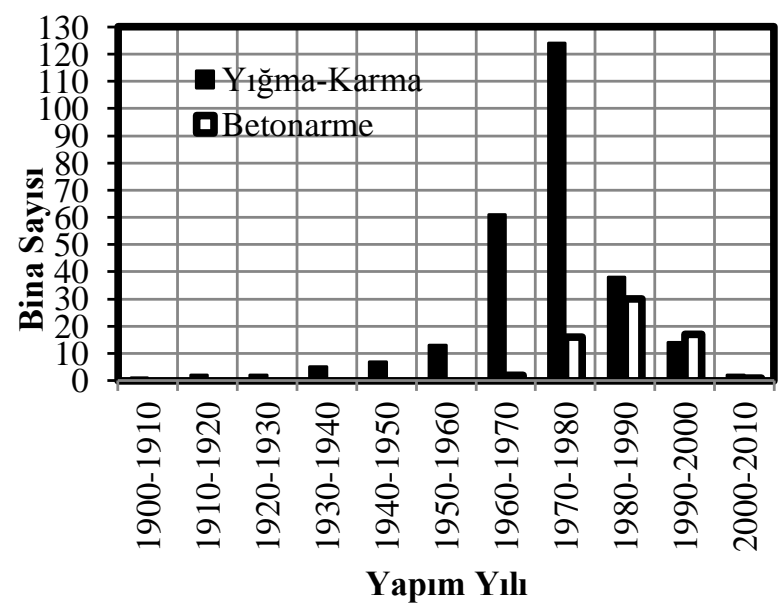

Şekil 1. İncelenen Betonarme Binaların Yapım Yılları

Kentsel dönüșüm kapsamında değerlendirilen binaların yükseklikleri ise 20 m'ye kadar ulaşabilmektedir. Şekil 2 incelendiğinde yığma ve karma binaların \% 99'nun yükseklikleri 15 m'nin altında, betonarme binaların ise 
Eskişehir Osmangazi Üniversitesi Mühendislik ve Mimarlık Fakültesi Dergisi 27(2), 60-66, 2019

\% 86 gibi büyük oranı 5-15 m aralığında olduğu söylenebilir.

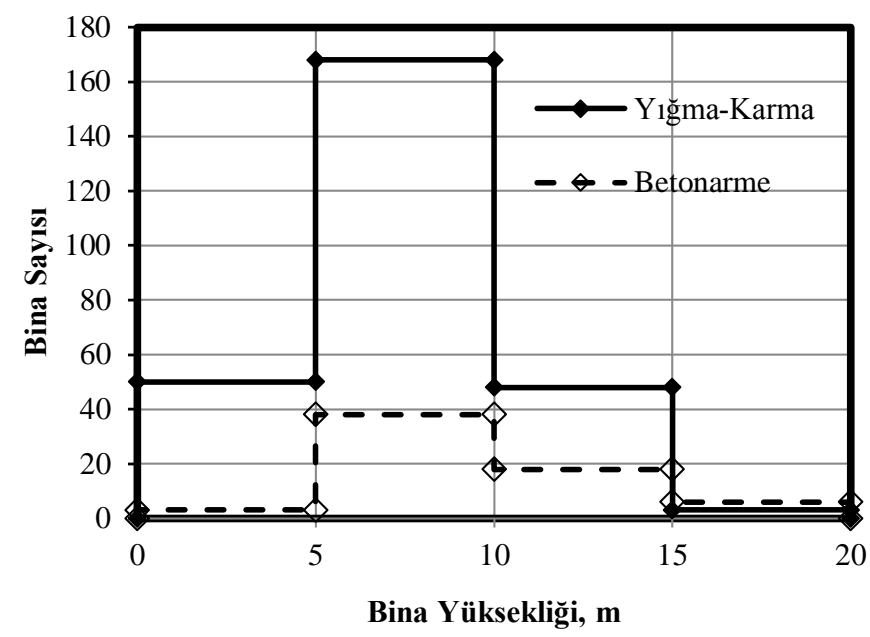

Şekil 2. Kentsel Dönüşüm Kapsamında Değerlendirilen Binaların Yükseklikleri

İncelenen binaların kat sayları ise 1-6 arasında değişmektedir. Şekil 3'de görüldüğü gibi kentsel dönüşüm için başvuran yığma ve karma yapıların \% 37'si 2 kat, betonarme binaların ise \% 35'i 3 katlı yapılardan oluşmaktadır. Burada dikkat çeken yığmakarma yapıların \% 1'e ulaşan kısmı 5 katın üzerinde inşa edilmiştir.

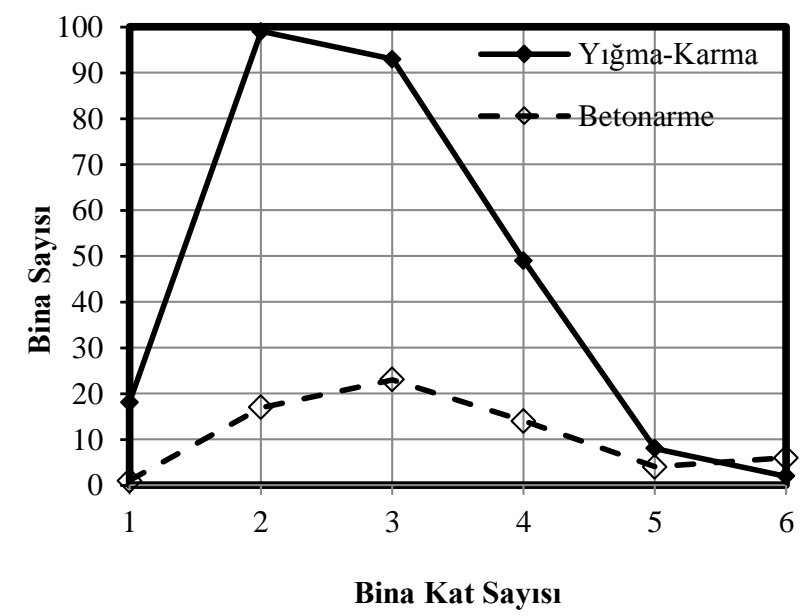

Şekil 3. Kentsel Dönüşüm Kapsamında Değerlendirilen Binaların Kat Sayıları

Bina toplam alanları en fazla $1800 \mathrm{~m}^{2}$ 'ye ulaşmaktadır. Şekil 4 incelendiğinde yığma ve karma binaların \% 80'ninden fazlasının bina toplam alanlarının $400 \mathrm{~m}^{2}$ nin altında olduğu, betonarme binaların ise \% 15'i 1000 $\mathrm{m}^{2}$ 'nin üzerinde olduğu belirlenmiștir. Bu kapsamda
Journal of Engineering and Architecture Faculty of Eskisehir Osmangazi University 27(2), 60-66, 2019

kentsel dönüșüme başvuran binaların toplam alanlarının genel olarak düşük olduğu söylenebilir.

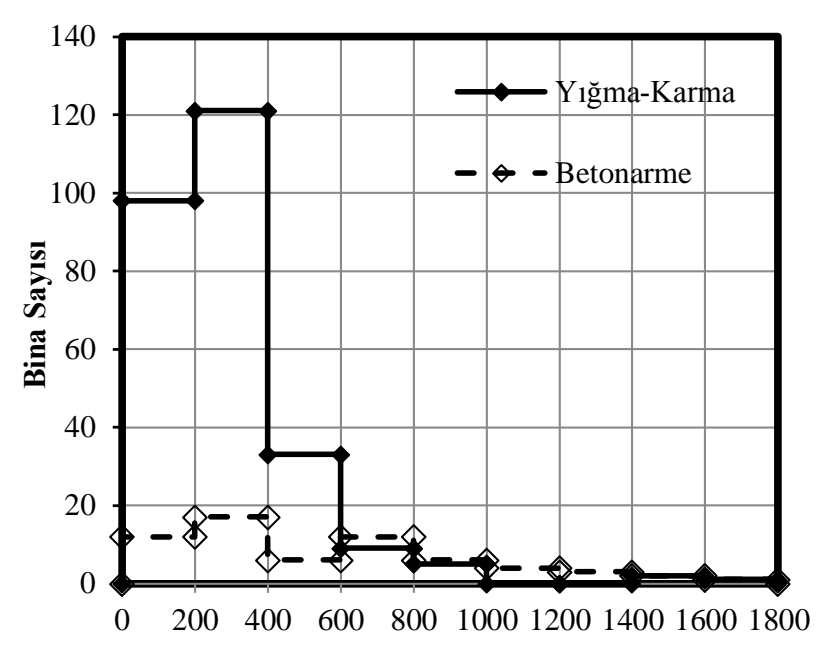

Toplam Alan, $\mathbf{m}^{2}$

Şekil 4. Kentsel Dönüşüm Kapsamında Değerlendirilen Binaların Toplam Alanları

\subsection{Yığma ve Karma Yapıların Değerlendirilmesi}

Yığma ve karma yapıların taşıyıcı duvar tipleri ve döșeme tipleri Şekil 6'da gösterilmektedir. Kentsel dönüșümü kapsamında incelenen yı̆̆ma ve karma binalarda taşıyıcı duvarların daha çok düșey delikli tuğlalardan oluştuğu belirlenmiştir. $\mathrm{Bu}$ binaların çoğunun yapım yıllarının 1970'li yıllar olduğu dikkate alınırsa harman tuğlası ve kerpiç kullanımının yaygın olması bu duvar çeşitlerinin dikkate değer oranlarda görülmesine neden olmuştur. Halen günümüzde köylerde kerpiç, briket, doğal taş kullanılarak yapılan yığma ve karma binaların ciddi miktarda olduğu görülmektedir. Özelikle kerpiç suya karşı dayanıksız bir yapı elemanıdır. Ayrıca bu kerpiç taşıyıcı duvarlı binaların nem alma durumunda her ne kadar tek katlı küçük yapılarda olsa deprem sırasında hareket kabiliyetinin olmaması bu yapılarda ciddi hasarlar ve kayıplar oluşmasına neden olduğu daha önceki depremlerde görülmüștür. Dolayısı ile bu yapıların kentsel dönüşüm kapsamında değerlendirilmesi önemlidir (Canbaz, Yılmaz, Şengel ve Kayalı, 2015). Yığma ve karma binaların çoğunluğu kirişli döșemelerden oluștuğu belirlenmiștir. Kırsal kesimde ve köylerde halen az katlı karma yapılar mevcut olup bunların çoğunluğunun döşemesinin ahşaptan oluştuğu söylenebilir. 
Eskişehir Osmangazi Üniversitesi Mühendislik ve Mimarlık Fakültesi Dergisi 27(2), 60-66, 2019
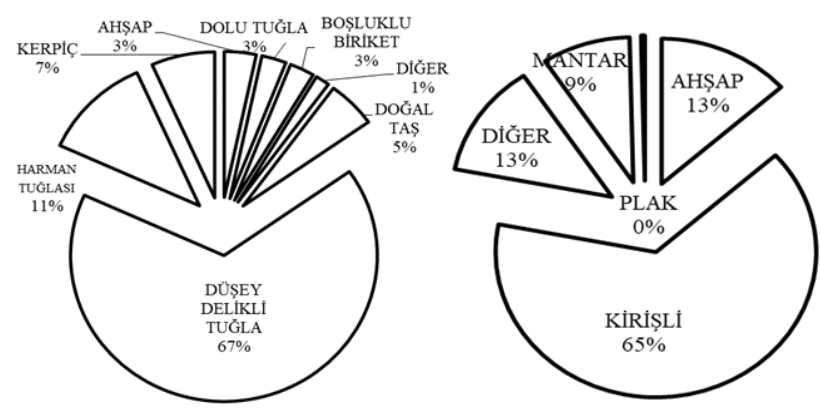

a) taşıyıcı duvar tipi

b) döşeme sistemi tipleri

Şekil 6. Kentsel Dönüșüm Kapsamında Değerlendirilen Yı̆̆ma-Karma Binaların Özelikleri

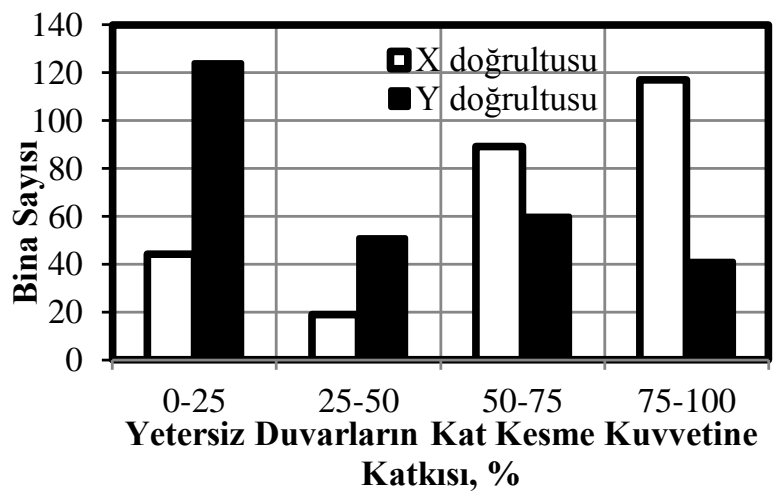

Şekil 7. Dayanımı yetersiz olan duvarların kat kesme kuvvetine katkısı

Yığma ve karma binaların yapısal olarak analizi, kritik katta meydana gelen taşıyıcı duvarların kesme dayanımının ve deprem etkisinde meydana gelen kesme kuvvetlerinin binanın her iki doğrultusu karşılaştırılması ile yapılır. Eğer dayanımı yetersiz olan duvarların kat kesme kuvvetine katkısı $\mathrm{X}$ veya $\mathrm{Y}$ yönünde \%50'nin üstünde ise, yapının riskli olduğu kabul edilmektedir (Canbaz ve diğ., 2015). Şekil 7'de dayanımı yetersiz olan duvarların kat kesme kuvvetine katkısı gösterilmiştir. Şekil 7 incelendiğinde bu katkının \% 0-100 arasında değiştiği gözlenmiştir. Her ne kadar sınır değer olan \% 50'nin altında çok sayıda bina olduğu görülse de bu grafikte $X$ ve $Y$ doğrultuları birbirinden bağımsız olarak değerlendirildiği için her iki doğrultuda da \% 50'nin üzerinde olan bina sayısı \% 28 ile sinırlı kalmıștır. Yığma ve karma binaların yapısal olarak analizinde tașıyıcı duvarların toplam uzunluk sınırı da yapı alanına bağlı olarak dikkate alınmaktadır. Burada pencere ve kapı gibi boşluklar dikkate alınmadan taşıyıcı duvar toplam uzunluğunun konsol döşeme hariç kat alanına bölünmesi ile elde edilen oran $X$ ve $Y$ doğrultusunda 0.2 'den az olmamalıdır. Bu oran yapının kullanım amacı ve önemine göre bina önem katsayısı ile çarpılarak arttırılabilir (Canbaz ve diğ., 2015). Kentsel
Journal of Engineering and Architecture Faculty of Eskisehir Osmangazi University 27(2), 60-66, 2019

dönüşüm kapsamında değerlendirilen yığma ve karma yapılar genellikle konut olarak kullanıldığı için bu yapıların bina önem katsayıları 1 olarak dikkate alınmış ve bu oranda artışa gidilmemiştir. Şekil 8'de taşıyıcı duvar toplam uzunluğunun brüt kat alanına oranı gösterilmiștir. Şekil 8 incelendiğinde bu oranın 0-0.8 arasında değiştiği gözlenmiştir. Sınır değer olan 0.2 oranının altında yapılar olduğu görülmüştür. Her iki doğrultuda da 0.2 oranın altında kalan yapı oranı \% 57 olmuştur.

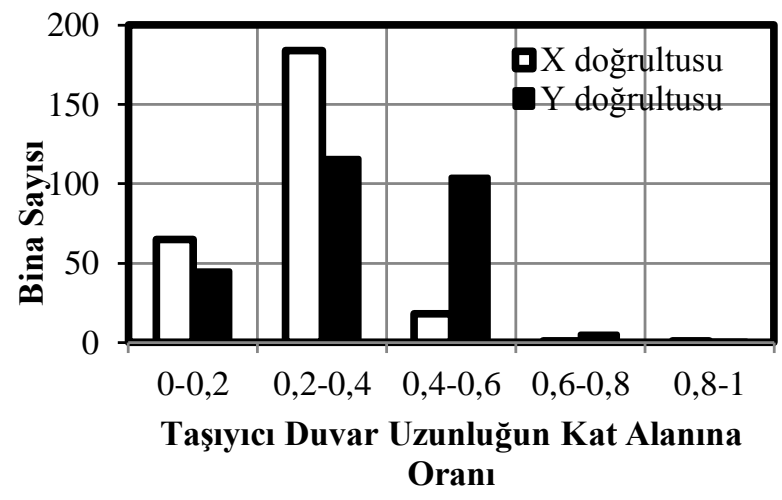

Şekil 8. Taşıyıcı Duvar Toplam Uzunluğunun Brüt Kat Alanına Oranı

\subsection{Betonarme Yapıların Değerlendirilmesi}

Şekil 9'da kentsel dönüşüm kapsamında incelenen betonarme yapıların inşa edildiği yıllara göre basınç dayanımları gösterilmiştir. Şekil 9 incelendiğinde; 1998 ve sonrasında yapılan betonarme binalardan kentsel dönüşümle ilgili yeterli başvuru yapılmadığı için 1998 deprem yönetmeliğine göre yapılan betonarme binaların basınç dayanım sonuçları değerlendirilememiştir. Kentsel dönüşüm için başvurusu yapılan betonarme binaların \% 83'ü 1975 deprem yönetmeliğine göre yapılmıștır. Bu yapıların basınç dayanımları 4-12.3 MPa aralığında değiștiği ve ortalamasının $7.56 \mathrm{MPa}$ olduğu görülmüștür. 1975 ve daha önce yapılan betonarme yapıların basınç dayanımları ise 5.6-15 $\mathrm{MPa}$ aralığında değişmiş ve ortalaması 9.81 MPa bulunmuştur. Hiçbir yapı deprem bölgeleri için kritik olan C20 beton basınç dayanım sınıfını sağlamamaktadır. 
Eskişehir Osmangazi Üniversitesi Mühendislik ve Mimarlık Fakültesi Dergisi 27(2), 60-66, 2019

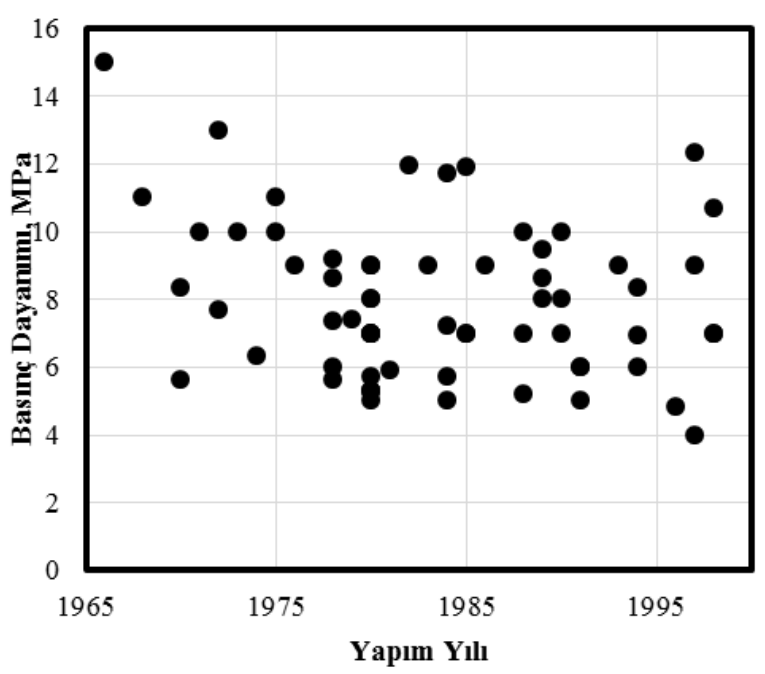

Şekil 9. Bina Yapım Yılı-Beton Basınç Dayanımı İlişkisi

Şekil 10 incelendiğinde betonarme yapıların 1 ile 6 katlı yapılar arasında olduğu görülmüștür. Bu yapıların genellikle 3 katlı oldukları tespit edilmiştir. İncelenen yapılardan alınan karot sonucu beton basınç dayanımlarının 5-11.9 $\mathrm{MPa}$ arasında değiştiği belirlenmiştir. İncelenen yapılarda basınç dayanımı 3.8$15 \mathrm{MPa}$ arasında değişmektedir. Deprem bölgelerinde yapılacak binalar hakkında yönetmelikteki (Deprem Bölgelerinde Yapılacak Binalar Hakkında Yönetmelik, 2007) C20 dayanım şartını sağlamayan yüksek katlı yapılar dikkat çekmektedir ve büyük risk oluşturmaktadır. C20 dayanım şartı Türkiye Bina Deprem Yönetmeliğine (Türkiye Bina Deprem Yönetmeliği, 2018) göre en az C25 olarak belirlenmiștir. 2000 yılından sonra yapılan yapılar C 20 dayanım şartını sağlasa da C25 şartını sağlayamamaktadır (Akdağ ve Karakurt, 2015).

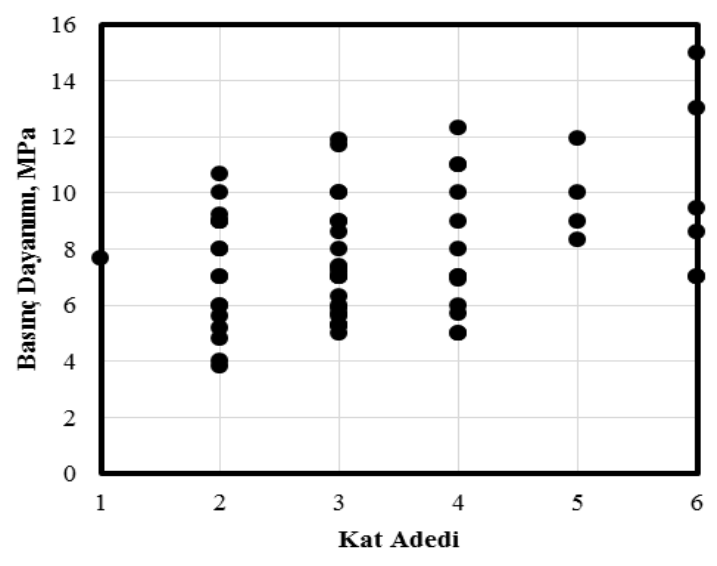

Şekil 10. Kat Adetlerine Göre Beton Basınç Dayanım Değerleri
Journal of Engineering and Architecture Faculty of Eskisehir Osmangazi University 27(2), 60-66, 2019

Betonarme yapılar incelenirken DBYBHY (2007)'e göre her bir katta 5 adet karot numunesi alınması gerekmektedir. $\mathrm{Bu}$ numunelerden elde edilen sonuçlarda ortalama dayanımının 20 MPa'ın altında olması durumunda bina riskli kabul edilmektedir (Canbaz ve Şengel, 2015). Şekil 11'de ise kentsel dönüşüm kapsamında analiz edilen betonarme yapıların karot numune sayısına göre dağılımı gösterilmiştir. Yapılan analizde toplam 66 adet yapıdan yaklaşı 63 tanesinde 5 ile 7 arasında karot alındığı belirlenmiştir. Ancak Deprem yönetmeliği incelendiğinde her bir katta 5 adet karot alınması gerektiği söylenmektedir. Bu çalışmada incelenen yapılar ortalama 3 katlı yapılar olduğuna göre alınması gereken karot numune sayısının en az 15 adet olması gerekmektedir. $\mathrm{Bu}$ analizlerde karot sayısının az olduğu söylenebilir. Türkiye Bina Deprem Yönetmeliğine (Türkiye Bina Deprem Yönetmeliği, 2018) göre karot sayısı kapsamlı bilgi düzeyi için zemin katta üç, diğer katlarda iki adetten az olmamak üzere ve binada toplam dokuz adetten az olmamak üzere belirlenmiştir. Sonuçların büyük kısmının bu değerleri de sağlamadığı görülmektedir.

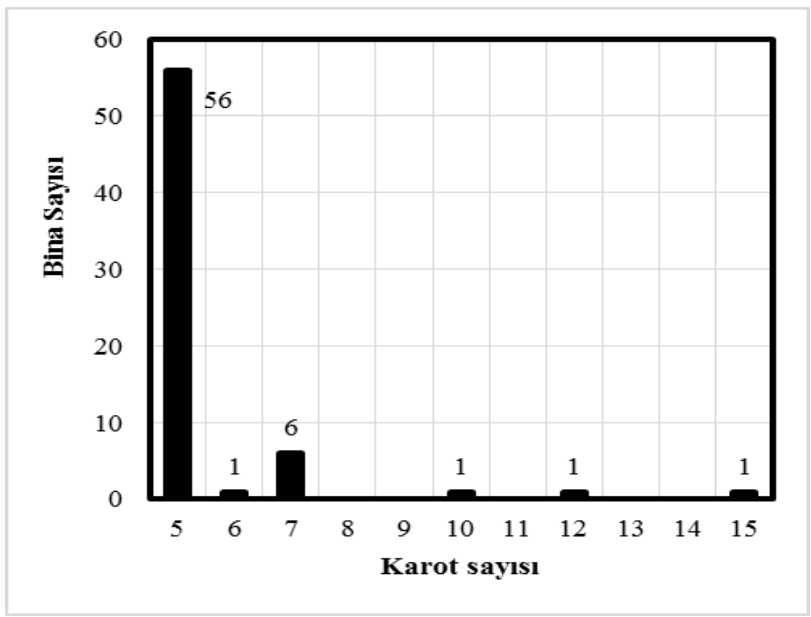

Şekil 11. Karot Numune Sayısına Göre Gözlem Değerleri

Şekil 12'de kentsel dönüşüm kapsamında incelenen betonarme yapıların basınç dayanımları gösterilmiştir. Basınç dayanım değerleri yapıdan alınan karot numunelerinin basınç dayanımlarına bağlı bulunan karakteristik dayanımıdır. 1 Ocak 1998 tarihli Afet Bölgelerinde Yapılacak Yapılar Hakkında Yönetmeliğe göre deprem bölgelerinde yapılacak betonarme yapılarda C16 sınıfından daha düşük dayanımlı beton kullanılamayacağı, 1 . ve 2. derece deprem bölgelerinde ise C20 sinıfı beton dayanımının minimum olması gerektiği belirtilmektedir (Canbaz ve Şengel, 2015). Türkiye Bina Deprem Yönetmeliğinde (Türkiye bina deprem yönetmeliği, 2018) ise C25 sinıfı beton 
Eskişehir Osmangazi Üniversitesi Mühendislik ve Mimarlık Fakültesi Dergisi 27(2), 60-66, 2019

dayanımının minimum olması gerektiği belirtilmektedir. Şekil 12'den de görüldüğü gibi incelenen betonarme yapılar bu kuralı sağlamamaktadır.

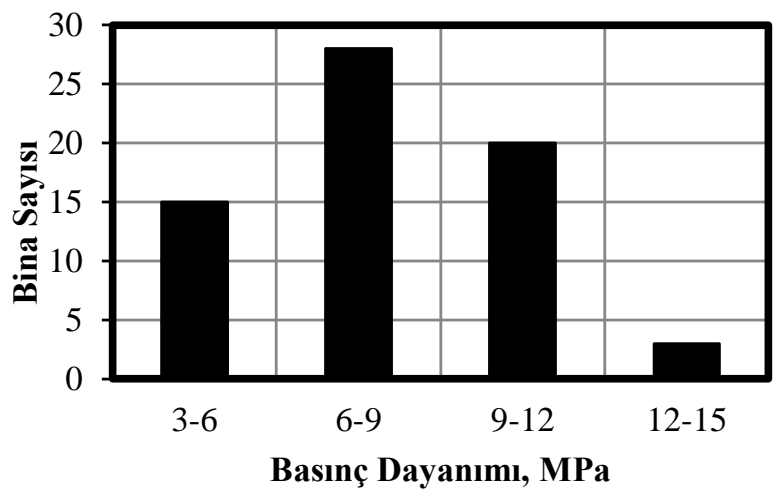

Şekil 12. Yapıların Beton Basınç Dayanımları

Tablo 1'de kentsel dönüşüm kapsamında incelenen betonarme binaların korozyon durumları gösterilmiștir. Binaların \%81.8'inde korozyon olmadığı görülmektedir. İncelenen yapıların korozyona uğramasında büyük bir risk görülmemiştir. Ancak korozyonun yapının taşıyıcı kısımlarında veya zemin-yapı etkileşim bölgelerinde farklı olabildiği, yapıda çatlak vb gibi boşluklar bulunması durumuna göre farklı bölgelerde değișebileceği belirtilmiştir (Canbaz ve Albayrak, 2007). Tablo 1'de binalarda mevcut donatı tipi S220 çeliği olduğu görülmüştür ancak günümüzde bu çelik kullanılmamaktadır. Günümüzde Türkiye Bina Deprem Yönetmeliğine göre (Türkiye bina deprem yönetmeliği, 2018) B420C ve B500C çelikleri kullanılabilmektedir.

Tablo 1.

İncelenen Yapılarda Döşeme Tipi, Donatı Sınıfı Ve Korozyon Durumu

\begin{tabular}{cccc}
\hline $\begin{array}{c}\text { Mevcut } \\
\text { donatı } \\
\text { Sinıfı }\end{array}$ & $\begin{array}{c}\text { Döșeme } \\
\text { tipi }\end{array}$ & $\begin{array}{c}\text { Donatıda korozyon durumu } \\
\text { Var }\end{array}$ & Yok \\
\hline S220 & Kirișli & $\% 18.2$ & $\% 81.8$ \\
\hline
\end{tabular}

\section{Sonuç ve Öneriler}

Kentsel dönüşüm yasasının yürürlüğe girdiği tarihten itibaren 2016 yılına kadar Kütahya'da bu kapsamda yapılan bireysel başvuru yöntemi ile toplam 66 adet betonarme ve 269 adet yığma-karma yapının incelenmesi sonucunda aşağıdaki sonuçlar elde edilmiştir:
Journal of Engineering and Architecture Faculty of Eskisehir Osmangazi University 27(2), 60-66, 2019

- Yapılan çalışmaya göre, yığma ve karma binaların \% 88'nin 1960-2000 yılları arasında yapıldığı, \% 80'nin toplam yapı alanının 400 $\mathrm{m}^{2 \prime}$ nin altında olduğu, \% 37'sinin 2 katlı yapılar olduğu, \% 99'nun yüksekliğinin 15 m'nin altında olduğu görülmüştür. Betonarme binaların ise \% 95'nin 1970-2000 yılları arasında yapıldığı, \% 15'nin toplam yapı alanının $1000 \mathrm{~m}^{2 \prime}$ nin üzerinde olduğu, \% 35'nin 3 katlı yapılar olduğu, \% 86'sınınn yüksekliğinin 5-15 m arasında değiștiği söylenebilir.

- Yığma ve karma binalar değerlendirildiğinde, taşıyıcı duvarlarda \% 67 oranında düşey delikli tuğla kullanıldığı, \% 7'sinde ise kerpiç kullanıldığı, bağlayıcı harç olarak çimento esaslı harçların kullanıldığı, kerpiç ve doğal taşların kullanılması durumunda ise daha düşük bağlayıcılığı olan çamurların kullanıldığı, döşeme sisteminin ise \% 65 oranında kirişli ve ahşap elemanlardan oluştuğu görülmüştür. Bu yapıların yapısal olarak analizi dikkate alındığında, yeterli dayanımı olmayan duvarların kat kesme kuvvetine katkısının her iki doğrultuda da \% 50'nin üzerinde olan bina sayısı \% 28 ile sınırlı kaldığı, boşluksuz olarak dikkate alınan taşıyıcı duvar uzunluğunun brüt kat alanına oranının ise sınır değer olan 0.2 oranının altında yapılar olduğu görülmüștür. Her iki doğrultu dikkate alındığında bu oran \% 57'ye ulaşmaktadır.

- İncelenen yapıların beton kalitesine bakıldığında basınç dayanımının 15 MPa'nın altında kaldığı görülmüștür. Mevcut deprem yönetmeliğine göre deprem bölgelerinde yer alan yapılarda basınç dayanımının en az $20 \mathrm{MPa}$ olması gerekmektedir. Yapılardan alınan karot sayısının büyük kısmı 8'in altındadır. Yapılardaki donatıların ise günümüzde kullanılmayan S220 (BÇI) sınıfı donatılar olduğu görülmüştür. Yapılarda yüksek oranda korozyon tespit edilememiştir. Ancak yer altı su seviyesinin yüksek olduğu, zemin-yapı etkileşim bölgelerinde betonarme yapı elemanlarında korozyon oluşumu kontrol edilmelidir.

Yığma ve karma yapıların riskini belirlemede deprem yönetmeliğinde belirtilen (Deprem Bölgelerinde Yapılacak Binalar Hakkında Yönetmelik, 2007) desteklenmemiş taşıyıcı duvar uzunluğu için sınır değerlerin, taşıyıcı duvarda boşluklar bulunması durumunda bu boşluk ve dolu kısımlara ait sınır değerlerin ve düzensizliklerinin, duvar kalınlıkları için sınır değerlerin, çatı oluşturulmasında en az koşulların sağlanıp sağlanmadığı da dikkate alınarak 
Eskişehir Osmangazi Üniversitesi Mühendislik ve Mimarlık Fakültesi Dergisi 27(2), 60-66, 2019

değerlendirme kapsamının genişletilmesi önerilebilir. Betonarme binaların kentsel dönüşüm kapsamında riskinin değerlendirmesinde mevcut deprem yönetmeliğinde belirtilen düzensizliklerin de dikkate alınması gerekmektedir. Bunun yanında yapı elemanlarının yapıdaki konumları dikkate alınarak karot sayısının arttırılması önerilmektedir. Yığma ve karma riskli yapılarda güçlendirme yerine kentsel dönüșüm kapsamında yenilenmesi önerilmektedir. Ancak özellikle kırsal kesimde ve köylerde deprem riski altında bulunan yapıların kentsel dönüşüm kapsamında maddi yetersizlikler nedeni ile yenilenememesi durumunda literatürde belirtilen (Önal ve Koçak, 2005) var olan çeşitli yöntemler ile güçlendirme önerilmektedir. Ayrıca bu gibi durumlar için kentsel dönüşüm kapsamı içinde güçlendirme içinde maddi ve teknik destek sağlanabilir.

\section{Çıkar Çatışması}

Yazarlar tarafından herhangi bir çıkar çatışması beyan edilmemiştir.

\section{Kaynaklar}

Afet Riski Altındaki Alanların Dönüștürülmesi Hakkında Kanun.(2012, 31 Mayıs). Resmi Gazete (Sayı: 28309). Erișim adresi: http://www.resmigazete.gov.tr/eskiler/2012/05/2 0120531-1.htm

Akdağ E., ve Karakurt C. (2015). Bilecik İlinde Bulunan Bazı Özel ve Kamu Yapılarındaki Beton Özelliklerinin İncelenmesi. Politeknik Dergisi, 18(1), 1-6. Erişim adresi: https://dergipark.org.tr/download/articlefile/385717

Beyaz A., ve Livaoğlu R. (2019). Bursa İli Kentsel Dönüşüm Çalışmalarında Elde Edilen Beton Basınç Dayanımının Değerlendirilmesi. Uludağ Üniversitesi Mühendislik Fakültesi Dergisi, 24 (1), 63-74. https://doi.org/10.17482/uumfd.486033

Canbaz M. ve Albayrak U. (2007), Assessment of Corrosion and Mechanical Properties of Rebar Used in a 50 Years-Old Reinforced Concrete Industrial Building, Engineering Optimization IV, Taylor\&Francis Group, London, ISBN 978-1-13802725-1, p. 809-814.

Canbaz M, Yılmaz İ, Şengel H.S. ve Kayalı E.M. (2015), Kentsel dönüşüm kapsamında Eskişehir yığma ve karma yapı stoğu. Uluslararası Kent Araştırmaları Kongresi Bildiriler Kitabı, 1322-1335, Eskişehir.

Canbaz M. ve Şengel H.S, (2015). Betonarme Binalarda Kentsel Dönüşüm Uygulamaları: Eskişehir. Bilecik Şeyh Edebali Üniversitesi Fen Bilimleri Dergisi, 2(2),
Journal of Engineering and Architecture Faculty of Eskisehir Osmangazi University 27(2), 60-66, 2019

9-15.

Erişim

adresi:

http://edergi.bilecik.edu.tr/index.php/fbd/article/ view/78/48.

Deprem Bölgelerinde Yapılacak Binalar Hakkında Yönetmelik. (2007, 6 Mart). Resmi Gazete (Sayı: 26454). Erişim adresi: http://www.resmigazete.gov.tr/eskiler/2007/03/2 0070306-3.htm

Genç, F.N. (2008). Türkiye'de Kentsel Dönüsüm: Mevzuat ve uygulamaların genel görünümü. Yönetim ve Ekonomi: Celal Bayar Üniversitesi İktisadi ve İdari Bilimler Fakültesi Dergisi, 15(1), 115-130. Erişim adresi:http://dergipark.ulakbim.gov.tr/yonveek/ar ticle/view/5000069205/5000064109

Önal, M. ve Koçak, A. (2005). Yığma Yapı Hasarları Ve Onarımı Ve Güçlendirme Yöntemlerinin Ayrıntıları. Antalya Yöresinin İnşaat Mühendisliği Sorunları Kongresi Bildiriler Kitabı, 93-108, Antalya.

Türkiye Bina Deprem Yönetmeliği. (2018, 18 Mart). Resmi Gazete (Sayı: 30364). Erişim adresi: http://www.resmigazete.gov.tr/eskiler/2018/03/2 $\underline{0180318 \mathrm{M} 1-2 . \mathrm{htm}}$ 